\title{
Patterns of lymphoma in Misan city, Iraq: A retrospective
}

\section{observational study [version 1; peer review: 1 approved with}

\section{reservations, 1 not approved]}

\author{
Haider Saadoon Qasim Alhilfi (D1, Omer Mansib Kassid2, \\ Husam Jihad Imran Jihad², Ahmed Salih Hussien Alshewered (iD3 \\ ${ }^{1}$ Department of Medicine, Faculty of Medicine, University of Misan, Misan, Iraq \\ 2Internal Medicine, Department of Medicine, Al-Sadder Teaching Hospital, Misan Health Directorate, Ministry of Health/ \\ Environment, Misan, Iraq \\ ${ }^{3}$ Radiotherapy and Clinical Oncology, Misan Radiotherapy Center, Misan, Iraq
}

V1 First published: 09 Oct 2019, 8:1733

https://doi.org/10.12688/f1000research.20723.1

Latest published: 09 Oct 2019, 8:1733

https://doi.org/10.12688/f1000research.20723.1

\section{Abstract}

Background: Lymphomas represent a biologically and clinically heterogeneous group of neoplasms. They have historically and clinically been divided into two groups, Hodgkin's lymphoma (HL) and non-Hodgkin's lymphoma (NHL). This study aimed to identify patterns in lymphomas in Misan city, Iraq, and evaluate the characteristics of this disease.

Methods: A retrospective, observational, single-center study was conducted at Al-Shifaa Oncology Center, Al-Sadder Teaching Hospital, Misan city, Iraq, between 1 April 2016 and 30 April 2018. A total of 80 Misanian participants (48 (60\%) men and 32 (40\%) women) who had lymphoma were involved in this study. The sources of information were patient files, histopathology reports, and patients' oncologist reports.

Results: The mean age ( \pm SD) of participants was $36 \pm 12.8$ years. The male to female ratio was 1.5:1. NHL cases were three times more prevalent than $\mathrm{HL}$. The most frequent stage at presentation was stage IV, in $34(42.5 \%)$ participants. The classical subtypes of HL were present in 14 (70\%) of HL cases. The diffuse large B-cell lymphoma (DLBCL) subtype was the most common NHL subtype, being recorded for 44 (73.3\%) of participants.

Conclusion: Lymphomas were more frequent in men. NHL was more common than $\mathrm{HL}$; one $\mathrm{HL}$ case was diagnosed for every three $\mathrm{NHL}$ cases. The most common histopathology of HL was mixed cellularity, while DLBCL was the most common subtype of NHL. Most cases presented at an advanced stage, resulting in a late diagnosis.

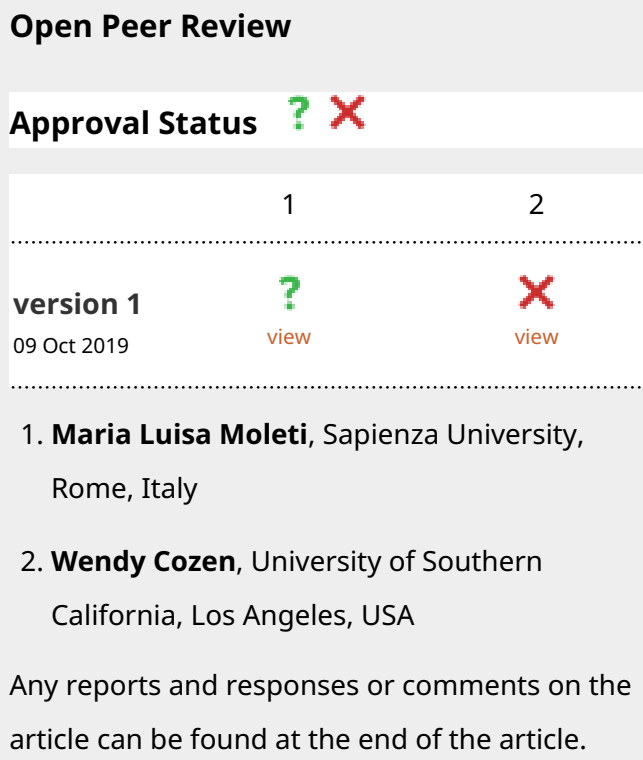

1 2 version 1 09 Oct 2019

$\begin{array}{cc}? & \mathrm{X} \\ \text { view } & \text { view }\end{array}$

1. Maria Luisa Moleti, Sapienza University, Rome, Italy

2. Wendy Cozen, University of Southern California, Los Angeles, USA

Any reports and responses or comments on the article can be found at the end of the article. 


\section{Keywords}

Non Hodgkin lymphoma, Hodgkin lymphoma, Misan, Lymphoid cells,

Iraq

\section{Corresponding author: Ahmed Salih Hussien Alshewered (ahmedalshewerd@gmail.com)}

Author roles: Alhilfi HSQ: Conceptualization, Data Curation, Formal Analysis, Investigation, Methodology, Resources, Supervision, Validation, Visualization, Writing - Original Draft Preparation, Writing - Review \& Editing; Kassid OM: Methodology, Project Administration, Resources, Supervision, Validation, Visualization, Writing - Original Draft Preparation; Jihad HJI: Conceptualization, Data Curation, Formal Analysis, Project Administration, Supervision, Validation, Visualization, Writing - Original Draft Preparation; Alshewered ASH: Formal Analysis, Methodology, Project Administration, Resources, Software, Validation, Visualization, Writing Original Draft Preparation, Writing - Review \& Editing

Competing interests: No competing interests were disclosed.

Grant information: The author(s) declared that no grants were involved in supporting this work.

Copyright: ( 2019 Alhilfi HSQ et al. This is an open access article distributed under the terms of the Creative Commons Attribution License, which permits unrestricted use, distribution, and reproduction in any medium, provided the original work is properly cited.

How to cite this article: Alhilfi HSQ, Kassid OM, Jihad HJI and Alshewered ASH. Patterns of lymphoma in Misan city, Iraq: A retrospective observational study [version 1; peer review: 1 approved with reservations, 1 not approved] F1000Research 2019, 8 :1733 https://doi.org/10.12688/f1000research.20723.1

First published: 09 Oct 2019, 8:1733 https://doi.org/10.12688/f1000research.20723.1 


\section{Introduction}

The term lymphoma refers to a heterogeneous group of neoplasms that originate from lymphoid cells. The majority $(85 \%)$ of lymphomas originate from mature B-cells, and 15\% derive from the T-cell lineage ${ }^{1}$. Historically and clinically, lymphomas have been divided into two groups, Hodgkin's lymphoma (HL) and non-Hodgkin's lymphoma (NHL). HL is characterized by the presence of Reed-Sternberg cells, which arise in a single lymph node or chain of lymph nodes and typically spread in a stepwise fashion to anatomically contiguous nodes ${ }^{1}$. The crude incidence of HL among Europeans is 2.3 per 100,000 individuals ${ }^{2}$. Young adults aged 20 to 40 years are most commonly affected ${ }^{1}$. Histologically, classical HL accounts for $95 \%$ of all HL cases ${ }^{1}$. The subtypes of classical lymphomas include nodular sclerosis (the most common subtype, comprising $60-65 \%$ of cases), mixed cellularity (15-30\%), lymphocyte-rich (5\%), and lymphocyte-depleted $(1 \%)^{1,3}$. HL patients present with peripheral lymphadenopathy, with nodes that are not tender, and with no overlying skin changes ${ }^{1,2}$. NHL are neoplastic transformations of mature B-, T-, or natural killer cells ${ }^{1}$. In children, diffuse large B-cell lymphoma (DLBCL), Burkitt's lymphoma, and lymphoblastic lymphoma are most common ${ }^{2-4}$. DLBCL is the most common histological subtype in adults ${ }^{4}$. The incidence increases with age, while a family history of lymphoma, autoimmune disease, human immunodeficiency virus infection, hepatitis $\mathrm{C}$ virus seropositivity, and a high body-mass as a young adult have all been identified as risk factors of DLBCL ${ }^{4,5}$.
Here, we describe a study designed to show patterns of lymphoma among patients in Misan who presented at our center. Since this group of neoplasms are curable diseases, we need to obtain more information about them to get a significant and timely picture about the current lymphoma situation in Iraq, and in Misan in particular.

\section{Methods}

Study design

This was a retrospective, observational, single-center study carried out in Misan city, Iraq to identify any patterns in lymphoma prevalence in this governmental administrative area.

\section{Setting}

The study was conducted at Al-Shifaa Oncology Center, Al-Sadder Teaching Hospital, Faculty of Medicine, Misan University, Misan city, Iraq, from 1 April 2016 to 30 April, 2018 (Figure 1). The recruitment dates began on the tenth day of each month and continued to the thirtieth day of that month. The period from the first day of the month until the ninth day was the time of patient follow-up. Data were collected on the last day of each month of the study.

\section{Participants}

A total of 80 participants (48 men and 32 women) from Misan who were diagnosed with lymphoma were included in this study. The age of participants ranged from 10 years to 80 years. Each patient had been previously diagnosed with lymphoma
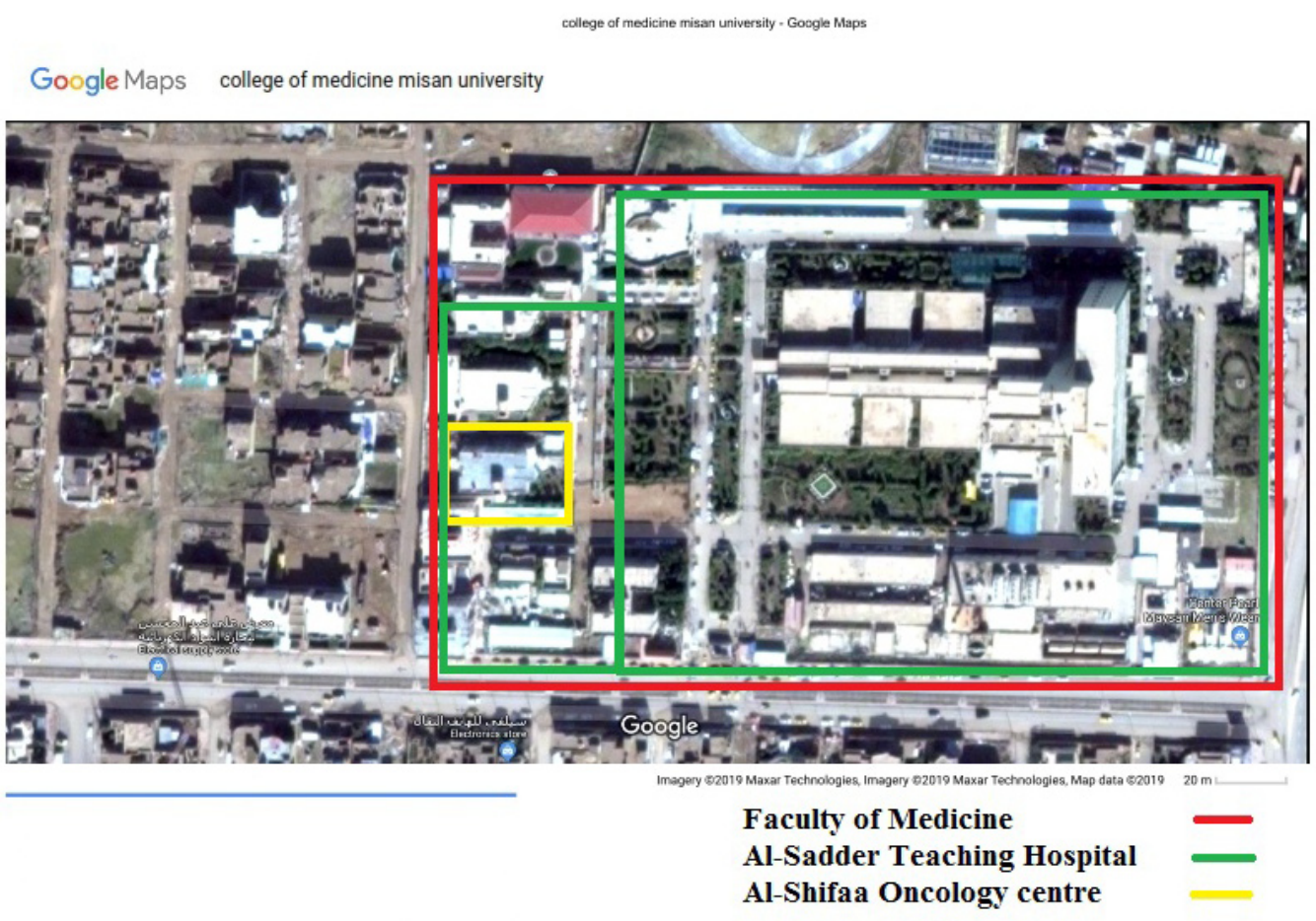

Figure 1. Al-Shifaa Oncology Center, Al-Sadder Teaching Hospital at the Faculty of Medicine. Imagery @2019 Maxar Technologies. 
and attended our center for chemotherapy. We included all patients diagnosed with lymphoma without any selectivity (the patients must live in Misan city). Sources of information included patient files, histopathology reports, and patient oncologist reports (these contained all of a patient's data written by his/her oncologist). Participant follow-up was performed on any day of nine days following a chemotherapy cycle.

\section{Variables}

History and investigation results were documented and recorded for each participant in his/her file, including age, type of residency, occupation, sex, diagnosis, stage of lymphoma, subtype of lymphoma, and class of lymphoma.

\section{Data sources/measurement}

The main sources of data were patient files and histopathology reports. Data written in the files included a patient's baseline characteristics, lymphoma baseline characteristics, and all investigations done.

\section{Study size}

We obtained this number of participants because we included all individuals with lymphoma without any selection methods.

\section{Ethical considerations}

Written informed consent was obtained from all participants, or the parents of those aged less than 18 years, to participate in this study. The Medical Ethical Committee at Al-Shifaa Oncology Center, Al-Sadder Teaching Hospital, Faculty of Medicine, Misan University approved this study (code: 1000552).

\section{Statistical analysis}

We used Microsoft Excel (v. 2010) to calculate frequencies and percentages of variables, and also to calculate means and standard deviations (SDs). This study did not have any missing data.

\section{Results}

All 80 participants included in this study were examined for eligibility and completion of follow-up. The mean age $( \pm \mathrm{SD})$ of participants was $36 \pm 12.8$ years. Half of the participants were in the 31-60 year age group, $24(30 \%)$ of participants were aged $>60$ years, and just $16(20 \%)$ belonged to the $10-30$ year age group. Most participants $(53 ; 67.5 \%)$ lived in rural areas, while $27(32.5 \%)$ lived in urban regions. The majority of patients were employed $(58 ; 72.5 \%)$. The male to female ratio was 1.5:1 (48 males and 32 females).

NHL was three-times more prevalent than HL, with $60(75 \%)$ and $20(25 \%)$ cases, respectively. Participants most frequently presented with stage IV, in $34(42.5 \%)$ of cases, followed by stage III in $24(32.5 \%)$, stage II in 12 (15\%), and stage I in $8(10 \%)$ cases. The classical subtypes of HL were most common, occurring in $14(70 \%)$ cases compared with $6(30 \%)$ cases who had nodular subtypes. The DLBCL subtype was most common among NHL subtypes, being recorded in $44(73.3 \%)$ of cases. Classical HL was subdivided into nodular sclerosis $(2 ; 14.3 \%)$, lymphatic-rich subtype $(4 ; 28.6 \%)$, and mixed cellularity $(8 ; 57.1 \%)$ (Table 1$)$. Table 1. Characteristics of patients with lymphoma in
Misan city, Iraq, April 2016 to April 2018.

\begin{tabular}{|c|c|c|}
\hline \multicolumn{2}{|c|}{ Variable $(n=80)$} & \multirow{2}{*}{$\begin{array}{l}\boldsymbol{n}(\%) \\
16(20)\end{array}$} \\
\hline Age, years & 10-30 & \\
\hline & $31-60$ & $40(50)$ \\
\hline & $\geq 60$ & $24(30)$ \\
\hline \multirow[t]{2}{*}{ Residence } & Rural & $53(67.5)$ \\
\hline & Urban & $27(32.5)$ \\
\hline \multirow[t]{2}{*}{ Occupation } & Not employed & $22(27.5)$ \\
\hline & Employed & $58(72.5)$ \\
\hline \multirow[t]{2}{*}{ Sex } & Male & $48(60)$ \\
\hline & Female & $32(40)$ \\
\hline \multirow[t]{2}{*}{ Diagnosis } & Hodgkin's lymphoma (HL) & $20(25)$ \\
\hline & Non-Hodgkin's lymphoma (NHL) & $60(75)$ \\
\hline \multirow[t]{4}{*}{ Staging } & I & $8(10)$ \\
\hline & ॥ & $12(15)$ \\
\hline & III & $26(32.5)$ \\
\hline & IV & $34(42.5)$ \\
\hline \multirow[t]{2}{*}{$H L(n=20)$} & Nodular & $6(30)$ \\
\hline & Classical (CHL) & $14(70)$ \\
\hline \multirow[t]{5}{*}{ NHL $(n=60)$} & Diffuse large B-cell & $44(73.3)$ \\
\hline & Follicular cell & $4(6.6)$ \\
\hline & Mantle cell & $6(10)$ \\
\hline & Burkett's & $2(3.4)$ \\
\hline & Peripheral T-cell & $4(6.6)$ \\
\hline \multirow[t]{3}{*}{ CHL $(n=14)$} & Nodular sclerosis & $2(14.3)$ \\
\hline & Lymphocyte rich & $4(28.6)$ \\
\hline & Mixed cellularity & $8(57.1)$ \\
\hline
\end{tabular}

\section{Discussion}

In our study, HL and NHL were recorded in $25 \%$ and $75 \%$ of cases, respectively, which is consistent with the results of a study conducted in Erbil city, in the north of Iraq ${ }^{6}$. The majority of HL cases presented as the classical subtype (70\%), while $30 \%$ of cases encountered were of the nodular subtype (30\%). The subtypes of classical HL included the nodular sclerosis (NS) subtype (14.3\%) and the lymphocyte-rich subtype $(28.6 \%)$, although the majority of cases comprised the mixed cellularity subtype $(57.1 \%)$. The most frequent histological subtype of HL was mixed cellularity, which differs from earlier reports from the north of $\operatorname{Iraq}^{5,6}$, but is consistent with earlier reports from nearby countries and India ${ }^{7-17}$. This changing pattern differs from more recent reports from Saudi Arabia, Jordan, United Arab Emirates (UAE), and Kuwait, where higher relative rates of NS HL were reported, approaching levels seen in the USA and in European countries ${ }^{12-17}$.

With regard to NHL subtypes, we found that the majority comprised DLBCL, followed by mantle cell, follicular cell, peripheral T-cell, and Burkitt's lymphoma. According to WHO classifications, DLBCL was also the most common diagnosis 
worldwide, at $52.2 \%$, followed by $\mathrm{T}$-cell rich lymphoma ${ }^{12}$. The relative proportion of DLBCL seen in the current study is almost twice the proportion seen in the USA and Europe, and is much higher than the proportion reported in India ${ }^{2,4,17,18}$, but is closer to figures reported from $\mathrm{UAE}^{14}$, Kuwait ${ }^{15}$, Jordan ${ }^{13}$, and Turkey ${ }^{19}$.

We found that the majority of lymphoma cases occurred in those aged 31 to 60 years, which was the same as findings in the USA and other countries ${ }^{15,18-20}$.

The majority of cases in our study presented at stage III or stage IV. Stage IV comprised $42.5 \%$ of cases and stage III $32.5 \%$, while the remainder were stage II (15\%) and stage I (10\%). These results are in agreement with the results of a study by Robert et $a .^{21}$
Limitations of this study include that it was a single-centre study, with a small number of participants, and the participants represent residents of the Misan government administrative area only.

\section{Conclusions}

This study showed that in Misan city, Iraq, lymphoma occurs most frequently among males. NHL is more common than HL, and the most common histopathology of HL is mixed cellularity, while DLBCL is the most common histopathology for NHL. Most cases presented with stage III or IV, which reflects delays in diagnosis, and decreases the chance of complete recovery, reflecting a more aggressive course and behavior of the disease.

\section{Data availability}

Zenodo: Lymphoma diseases patients patterns in Misan Government, http://doi.org/10.5281/zenodo.3458806²2.
1. Cheson BD, Fisher RI, Barrington SF, et al:: Recommendations for initial evaluation, staging, and response assessment of Hodgkin and nonHodgkin lymphoma: the Lugano classification. J Clin Oncol. 2014; 32(27): 3059-3068.

PubMed Abstract | Publisher Full Text | Free Full Text

2. Sant M, Allemani C, Tereanu C, et al:: Incidence of hematologic malignancies in Europe by morphologic subtype: results of the HAEMACARE project. Blood. 2010; 116(19): 3724-3734.

PubMed Abstract | Publisher Full Text

3. Morton LM, Slager SL, Cerhan JR, et al:: Etiologic heterogeneity among nonHodgkin lymphoma subtypes: the InterLymph Non-Hodgkin Lymphoma Subtypes Project. J Natl Cancer Inst Monogr. 2014; 2014(48): 130-144. PubMed Abstract | Publisher Full Text | Free Full Text

4. Sant M, Minicozzi P, Mounier M, et al:: Survival for haematological malignancies in Europe between 1997 and 2008 by region and age: results of EUROCARE-5, a population-based study. Lancet Oncol. 2014; 15(9): 931-942. PubMed Abstract | Publisher Full Text

5. Yahya HI, Al-Saleem T, Tikriti F, et al.: Hodgkin's disease in Iraq: a clinicopathologic study of 85 cases. Clin Oncol. 1979; 5(1): 69-71. PubMed Abstract

6. Alsabti EA: Histopathological subtypes of Hodgkin's disease in childhood in Iraq. Jpn J Exp Med. 1979; 49(5): 319-24.

PubMed Abstract

7. Almasri N, Thunold S, Devi KR, et al.: Hodgkins lymphoma in North Jordan Does it have a different pattern? Saudi Med J. 2004; 25(12): 1917-21. PubMed Abstract

8. Bamanikar S, Thunold S, Devi KR, et al.: The pattern of malignant lymphoma in Oman. J Trop Med Hyg. 1995; 98(5): 351-4. PubMed Abstract

9. Shome DK, George SM, Al-Hilli F, et al: Spectrum of malignant lymphomas in Bahrain. Leitmotif of a regional pattern. Saudi Med J. 2004; 25(2): 164-7. PubMed Abstract

10. Alsabti EA: Histopathological subtypes of Hodgkin's disease in childhood in Iraq. Jpn J Exp Med. 1979; 49(5): 319-24. PubMed Abstract

11. Al-Bahrani ZR, Al-Mondhiry H, Bakir F, et al:: Clinical and pathologic subtypes of primary intestinal lymphoma. Experience with 132 patients over a 14-yea period. Cancer. 1983; 52(9): 1666-72. PubMed Abstract | Publisher Full Tex

12. Al-Diab Al, Siddiqui N, Sogiawalla FF, et al:: The changing trends of adult
Hodgkin's disease in Saudi Arabia. Saudi Med J. 2003; 24(6): 617-22. PubMed Abstract

13. Haddadin WJ: Malignant lymphoma in Jordan: a retrospective analysis of 347 cases according to the World Health Organization classification. Ann Saudi Med. 2005; 25(5): 398-403.

PubMed Abstract | Publisher Full Text | Free Full Text

14. Castella A, Joshi S, Raaaschou T, et al.: The Pattern of malignant lymphoma in the United Arab Emirates--a histopathologic and immunologic study in 208 native patients. Acta Oncol. 2002; 40(5): 660-4. PubMed Abstract | Publisher Full Text

15. al-Bahar S, Pandita R, al-Bahar E, et al:: Recent trends in the incidence of lymphomas in Kuwait. Neoplasma. 1996; 43(4): 253-7. PubMed Abstract

16. Anderson JR, Armitage JO, Weisenburger DD: Epidemiology of the nonHodgkin's lymphomas: distributions of the major subtypes differ by geographic locations. Non-Hodgkin's Lymphoma Classification Project. Ann Oncol. 1998; 9(7): 717-20. PubMed Abstract | Publisher Full Text

17. Naresh KN, Srinivas V, Soman CS: Distribution of various subtypes of nonHodgkin's lymphoma in India: a study of 2773 lymphomas using R.E.A.L. and WHO Classifications. Ann Oncol. 2000; 11 Suppl 1: 63-7. PubMed Abstract | Publisher Full Text

18. Naresh KN, Agarwal B, Nathwani BN, et al:: Use of the World Health Organization (WHO) classification of non-Hodgkin's lymphoma in Mumbai, India: a review of 200 consecutive cases by a panel of five expert hematopathologists. Leuk Lymphoma. 2004; 45(8): 1569-77. PubMed Abstract | Publisher Full Text

19. Isikdogan A, Ayyildiz O, Buyukcelik A, et al:: Non-Hodgkin's lymphoma in southeast Turkey: clinicopathologic features of 490 cases. Ann Hematol. 2004; 83(5): 265-9. PubMed Abstract | Publisher Full Text

20. Naresh KN, Advani S, Adde M, et al.: Report of an International Network of Cancer Treatment and Research workshop on non-Hodgkin's lymphoma in developing countries. Blood Cells Mol Dis. 2004; 33(3): 330-7. PubMed Abstract | Publisher Full Text

21. Newton R, Ferlay J, Beral V, et al:: The epidemiology of non-Hodgkin's lymphoma: comparison of nodal and extra-nodal sites. Int J Cancer. 1997; 72(6): 923-30. PubMed Abstract | Publisher Full Text

22. Alhelfi HQ: Lymphoma diseases patients patterns in Misan Government. 2019 http://www.doi.org/10.5281/zenodo.3458806 


\section{Open Peer Review}

\section{Current Peer Review Status: ? $\mathrm{X}$}

\section{Version 1}

Reviewer Report 26 August 2020

https://doi.org/10.5256/f1000research.22791.r58788

(C) $\mathbf{2 0 2 0}$ Cozen $\mathbf{W}$. This is an open access peer review report distributed under the terms of the Creative Commons Attribution License, which permits unrestricted use, distribution, and reproduction in any medium, provided the original work is properly cited.

\section{Wendy Cozen}

Departments of Preventive Medicine and Pathology, Keck School of Medicine of USC, University of Southern California, Los Angeles, CA, USA

This study describes characteristics of lymphoma patients at a teaching hospital in Misan, Iraq. The subject matter is interesting because the distribution of histologic subtype of lymphoma varies internationally. There is not much known about the distribution of lymphoma types in Iraq so this study will contribute knowledge.

However, the authors miss an opportunity to present more useful data and there are a few problems with the way the paper is written. Comments are below:

1. The representativeness of the lymphoma patients diagnosed at Misan University hospital is unclear. What \% of all patients in the region are diagnosed at this hospital? Does the hospital preferentially treat refractory or difficult cases? More details are needed to understand the generalizability of the patients to the Iraqi population.

2. Figure 1 is not necessary.

3. Table 1 - frequencies should be presented by sex.

4. Additional details would be helpful, for example, what is the distribution of germinal center vs. activated B-cell among DLBCL cases? How many of the Hodgkin lymphoma cases are $\mathrm{EBV}+$ ?

5. The characteristics in Table 1 should be stratified by Hodgkin and non-Hodgkin lymphoma and not lumped together.

6. A pie chart might be a better way to show the histological distributions, perhaps comparing to other countries.

Is the work clearly and accurately presented and does it cite the current literature? 
Partly

Is the study design appropriate and is the work technically sound?

No

Are sufficient details of methods and analysis provided to allow replication by others? No

If applicable, is the statistical analysis and its interpretation appropriate?

No

Are all the source data underlying the results available to ensure full reproducibility? No

Are the conclusions drawn adequately supported by the results?

Yes

Competing Interests: No competing interests were disclosed.

Reviewer Expertise: Epidemiology and pathology of hematologic neoplasms.

I confirm that I have read this submission and believe that I have an appropriate level of expertise to state that I do not consider it to be of an acceptable scientific standard, for reasons outlined above.

Reviewer Report 26 August 2020

https://doi.org/10.5256/f1000research.22791.r67869

(c) $\mathbf{2 0 2 0}$ Luisa Moleti M. This is an open access peer review report distributed under the terms of the Creative Commons Attribution License, which permits unrestricted use, distribution, and reproduction in any medium, provided the original work is properly cited.

\section{Maria Luisa Moleti}

Department of Translational and Precision Medicine, Sapienza University, Rome, Italy

The authors report the results of a retrospective study conducted at Al-Shifaa Oncology Center, AlSadder Teaching Hospital, Misan city, Iraq, on 80 lymphoma patients diagnosed and treated from April 2016 to April 2018. The aim of the study was to describe the histopathological and clinical patterns of lymphoma patients from the Misan area.

The important issue of the spectrum of lymphomas in the different geographic areas is the object of several reports and this paper could add new data regarding the Middle East area. However, some comments need to be made.

\section{Introduction}

The Introduction should focus primarily on the topic of different histological lymphoma 
subtypes in different geographic areas.

\section{Methods}

Information concerning the Histopathologic Classification system, Stadiation system and stadiation modality, and also the inclusion criteria are not described.

The methods description is repetitive and unclear and is not completely congruent with the objectives and results of the study. For example:

1)"The recruitment dates began on the tenth day of each month and continued to the thirtieth day of that month. The period from the first day of the month until the ninth day was the time of patient follow-up. Data were collected on the last day of each month of the study."

What do the authors mean? It is not clear. Why do the authors mention the follow-up? It is not relevant to this study.

2) "We included all patients diagnosed with lymphoma without any selectivity (the patients must live in Misan city)".

What do the authors mean? It is not clear.

3) "Study size"

Can be omitted. It does not make sense; moreover, the authors already mentioned that all diagnosed patients were included.

\section{Results}

The authors could describe the results in a more detailed table, distinguishing the characteristics of the patients with $\mathrm{HL}$ and $\mathrm{NHL}$, both for the entire population and also according to the three different age ranges.

Median age instead of mean age may give more information on the age distribution.

How many patients are in the pediatric age $(<15)$ ? This is relevant because of the different histological distribution of pediatric lymphomas.

The description of the clinical presentation is missing; it could add interest to the study and could be included in the table.

\section{Discussion}

The authors compare their results to the literature in detail. Other more recent papers on the same topic may be included in the discussion. A table comparing the results of papers reporting the Middle East lymphoma distribution might be interesting.

Some comments on the low incidence of low-grade lymphomas might be interesting.

\section{References}

In the literature, there are other papers on this topic, for example, Perry, Hematologica 2016, (NHL in the developing world) ${ }^{1}$; Gross, Br J. Hematol 2016, (pediatric population in LIC) 2; Monabati, Ann. Hematol. 2016 and Mozaheb, Cancer Epidemiology 2011 (data from Iran) ${ }^{3}$ 14; Saglam, Turkish Journal of Medical Sciences 2018 (data from Turkey). ${ }^{5}$

\section{References}


1. Perry AM, Diebold J, Nathwani BN, MacLennan KA, et al.: Non-Hodgkin lymphoma in the developing world: review of 4539 cases from the International Non-Hodgkin Lymphoma Classification Project.Haematologica. 101 (10): 1244-1250 PubMed Abstract | Publisher Full Text

2. Gross TG, Biondi A: Paediatric non-Hodgkin lymphoma in low and middle income countries.Br J Haematol. 173 (4): 651-4 PubMed Abstract | Publisher Full Text

3. Monabati A, Safaei A, Noori S, Mokhtari M, et al.: Subtype distribution of lymphomas in South of Iran, analysis of 1085 cases based on World Health Organization classification.Ann Hematol. 2016; 95 (4): 613-8 PubMed Abstract | Publisher Full Text

4. Mozaheb Z, Aledavood A, Farzad F: Distributions of major sub-types of lymphoid malignancies among adults in Mashhad, Iran.Cancer Epidemiol. 2011; 35 (1): 26-9 PubMed Abstract | Publisher Full Text

5. Sağlam A, Esin E, Hayran M, Boyraz B, et al.: Distribution of lymphomas in Turkey: data of 4239 cases from a single institution using the WHO classification. Turk J Med Sci. 2018; 48 (5): 1013-1023 PubMed Abstract | Publisher Full Text

Is the work clearly and accurately presented and does it cite the current literature? Partly

Is the study design appropriate and is the work technically sound? Partly

Are sufficient details of methods and analysis provided to allow replication by others? Partly

If applicable, is the statistical analysis and its interpretation appropriate? Not applicable

Are all the source data underlying the results available to ensure full reproducibility? No source data required

Are the conclusions drawn adequately supported by the results? Partly

Competing Interests: No competing interests were disclosed.

Reviewer Expertise: Pediatric and Young adult hematological malignancies, particularly Hodgkin and non Hodgkin lymphomas,

I confirm that I have read this submission and believe that I have an appropriate level of expertise to confirm that it is of an acceptable scientific standard, however I have significant reservations, as outlined above. 
The benefits of publishing with F1000Research:

- Your article is published within days, with no editorial bias

- You can publish traditional articles, null/negative results, case reports, data notes and more

- The peer review process is transparent and collaborative

- Your article is indexed in PubMed after passing peer review

- Dedicated customer support at every stage

For pre-submission enquiries, contact research@f1000.com 